\title{
KEDUDUKAN KETETAPAN MPR PASCA AMANDEMEN KONSTITUSI
}

\author{
Rooza Meilia Anggraini \\ Institut Agama Islam Riyadlotul Mujahidin (IAIRM) Ngabar Ponorogo \\ mayrooza@gmail.com
}

\begin{abstract}
After the amendment of UUD 1945, MPR is no longerthe highest state institution in Indonesia. This change had an effect on the function of the MPR. MPR just like a joint forum between the DPR and DPD. Amendments of UUD 1945 produce Institutions in horizontal functional relations, not in vertical structural relationships. This certainly has an impact on the legal products issued by the MPR, namely the TAP MPR. Then the legal products that can be outlined in the TAP MPR are only determination (beschikking), for example the determination of someone elected to be President and/or Vice President. Therefore the MPR regulation which is regulating as in the past will nolonger exist. But on the other hand the re-inclusion of the TAP MPR in the hierarchy of laws will lead to new problems, how to purpose judisial review ofTAP MPR if it contradicts with the UUD 1945, while the authority of the Constitutional Court is limited to testing the Law to the Constitution. And till nowthere are not specific provisions to solve that. One way that can be doing is through legislative review conducted by that institution.
\end{abstract}

Keyword: the position of TAP MPR, After Amendment

\begin{abstract}
Abstrak
Pasca diamandemennya Undang Undang Dasar Tahun 1945, MPR tidak lagi menjadi lembaga tertinggi Negara. Perubahan ini membawa akibat pada fungsi MPR yang menjadi sebuah forum gabungan join session antara DPR dan DPD. Amandemen UUD 1945 menghasilkan Lembaga Negara dalam hubungan funsional yang horizontal, bukan dalam hubungan structural vertical. Hal ini tentu berdampak kepada produk hukum yang dikeluarkan oleh MPR, yakni Ketetapan MPR. Maka produk hukum yang dapat dituangkan dalam ketetapan MPR hanyan keputusan yang bersifat penetapan (beschikking) saja misalnya penetapan seseorang terpilih menjadi Presiden dan/atau Wakil Presiden. Dengan demikian Ketetapan MPR yang bersifat mengatur (regiling) seperti di masa lalu tidak aka ada lagi. Namun disisi lain kembali dimasukkannya TAP MPR dalam hirarki peraturan perundang undangan akan menimbulkan permasalahan baru, yakni bagaimana melakukan pengujian materi terhadap TAP MPR jika bertentangan dengan UUD 1945, sedangkan wewenang Mahkamah Konstitusi hanya terbatas sampai pada pengujian Undang Undang terhadap UUD. Dan sampai saat ini belum ada ketentuan khusus baik di tingkat UUD maupun Undang Undang lainnya yang menerangkan tentang pengujian materi terhadap TAP MPR. Salah satu cara yang dapat dilakukan yaitu melalui legislative review yang dilakukan lembaga itu sendiri dengan cara dibatalkan atau diubah melalui TAP MPR juga.
\end{abstract}

\section{Kata Kunci: Kedudukan TAP MPR, Pasca Amandemen}

\section{Pendahuluan}

Perubahan ketiga UUD 1945 diputuskan pada Rapat Paripurna MPR-RI Ke 7, menurut Sri Sumantri perubahan ketiga dilakukan menurut teori konstitusi, terhadap susunan ketatanegaraan yang bersifat mendasar. Bahkan subtansi penjelasan yang sifatnya normative dimasukkan dalam batang tubuh UUD 1945. ${ }^{1}$ Perubahan substansi amandemen ketiga meliputi antara lain: (1)

\footnotetext{
${ }^{1}$ Titik Triwulan Tutik, Konstruksi Hukum Tata Negara Indonesia Pasca Amandemen UUD 1945, (Surabaya: Kencana. 2008), 3
} 
kedudukan dan kekuasaan MPR; (2) Eksistensi Negara hukum Indonesia; (3) jabatan Presiden dan Wakil Presiden termasuk mekanisme pemilihan; (4) pembentukan lembaga baru dalam sistem ketatanegaraan RI; (5) Pengaturan tambahan bagi lembaga DPK; dan (6) Pemilu.

Setelah perubahan UUD, MPR tidak lagi memiliki kewenangan menetapkan GBHN dan tidaklagi mengeluarkan Ketetapan MPR (TAP MPR), kecuali berkenaan dengan menetapkan Wapres menjadi Presiden, memilih Wapres apabila terjadi kekosongan Wapres, atau memilih Presiden dan Wakil Presiden apabila Presiden dan Wakil Presiden mangkat, berhenti, diberhentikan, atau tidak dapat melakukan kewajibannya dalam masa jabatannya secara bersama-sama. Setelah amandemen,MPR berkedudukan sebagai lembaga tinggi negara yang setara dengan lembaga tinggi negara lainnya. ${ }^{2}$

Berkaitan dengan adanya perubahan kedudukan MPR ternyata juga berpengaruh terhadap kedudukan TAP MPR dalam hirarki peraturan perundang undangan di Indonesia. Menurut Undang Undang No. 12 Tahun 2011 tentang Pembentukan Peraturan Perundang-undangan, yang menegaskan bahwa, jenis dan hierarki Peraturan Perundang-undangan terdiri atas :

1. Undang-Undang Dasar Negara Republik Indonesia Tahun 1945

2. Ketetapan Majelis Permusyawaratan Rakyat

3. Undang-Undang/Peraturan Pemerintah Pengganti Undang-Undang

4. Peraturan Pemerintah

5. Peraturan Presiden

6. Peraturan Daerah Provinsi

7. Peraturan Daerah Kabupaten/Kota

Dimasukkannya kembali TAP MPR dalam hirarki peraturan perundang undangan di Indonesia menunjukkan bahwasannya TAP MPR masih menjadi sumber hukum yang memiliki kekuatan hukum mengikat bagi seluruh WNI, Namun bagaimana jika MPR bukan lagi menjadi lembaga tertinggi Negara, hal ini tentu berdampak terhadap kedudukan produk hukum yang dihasilkan oleh MPR jika produk hukum yang dihasilkan tersebut bertentangan dengan peraturan perundang undangan diatasnya yaitu UUD 1945 atau sebaliknya TAP MPR tersebut bertentangan dengan peraturan perundang undangan dibawahnya, apakah bisa diajukan yudisial review ke Mahkamah Agung untuk produk hukum dari lembaga legislative ini.

\section{Pembahasan}

Di dalam UUD 1945 tidak ditemukan secara tegas peraturan prundang undangan berupa ketetapan MPR, ketetapan MPR baru mulai dikenal pada saat sidang sidang MPRS tahun 1966.Tidak adanya pengaturan yang tegas dalam UUD 1945 berkaitan dengan ketetapan MPR menimbulkan perbedaan pendapat di kalangan ahli hukum tata Negara.Sri Soemantri maupun Bagir Manan menganggap bahwa munculnya ketetapan MPR sebagai peraturan perundang undangan sebagai konsekuensi logis dari kewenangan yang dimiliki oleh MPR. ${ }^{3}$

Lebih lanjut Bagir Manan menyebutkan dua landasan ketetapan MPR: pertama, ketentuan ketentuan yang tersirat sekaligus mengandung kekuasaan tersurat diakui oleh setiap sistem UUD. MPR menurut UUD 1945 pasca amandemen adalah wewenang mengubah dan menetapkan UUD, memberhentikan presiden dan wakil presiden dalam masa jabatannya, atas dasar usulan DPR dalam perkara impeachment dan menentapkan presiden pengganti. Keputusan keputusan hukum ini yang berasal dari kewenangan MPR harus diberi bentuk hukum tertentu yakni berupa ketetapan.

Kedua, dasar kedua bagi kehadiran TAP MPR adalah praktek ketatanegaraan atau kebiasaan ketatanegaraan. Kebiasaan ketatanegaraan merupakan salah satu sumber hukum tata Negara dan terdapat pada setiap Negara. ${ }^{4}$

\footnotetext{
${ }^{2}$ Irwandi, 'Kedudukan TAP MPR Dan Implikasinya Terhadap Hierarki Peraturan Perundang Undangan Di Indonesia', Inovatif, 6.2 (2013), 3.

${ }^{3}$ Sirajudin, Legislative Drafting,( Malang: Setara Press, 2016) 63.

${ }^{4}$ Ibid., 64.
} 
Sebelum dilakukan perubahan UUD 1945 materi muatan TAP MPR tidak hanya terbatas pada hal hal yang secara tegas menjadi kewenangan MPR, tetapi termasuk hal hal lain, dasar yang digunakan MPR adalah pasal 3 UUD 1945 yang menyebutkan bahwasannya kekuatan MPR tidak terbatas. Namun setelah dilakukan amandemen sampai dengan amandemen keempat secara tegastegas sudah diatur dalam pasal 1 ayat (2) bahwa "kedaulatan berada di tangan rakyat dan dilaksanakan menurut UUD”.Ini artinya kekuasaan MPR tidak lagi tak terbatas, dengan kata lain TAP MPR harus sesuai dan tidak boleh bertentangan dengan UUD.

Dimasa lalu, konsekuensi dari kedudukan dan kewenangan MPR untuk menetapkan Garis Garis Besar daripada Haluan Negara (GBHN), mengakibatkan eksistensi TAP MPR(S) sebagai salah satu pengaturan perundang-undangan yang memuat pengaturan. Hal ini kemudian semakain dipertegas dengan adanya Ketetapan MPRS Nomor XX/MPRS/1966 yang menempatkan TAP MPR sebagai salah satu peraturan perundang-undangan yang memiliki derajat di bawah UUD. Namun menurut Mahfud MD, menempatkan TAP MPR sebagai peraturan perundang-undangan dalam derajat kedua (di bawah UUD 1945) sebenarnya hanyalah tafsiran MPRS saja, sebab UUD sendiri tidak menyebutkan bahwa TAP MPR itu harus berisi pengaturan (regeling) dan berbentuk peraturan perundang-undangan. ${ }^{5}$

Dalam periode era reformasi, TAP MPR dianggap sebagai perpanjangan tangan dari kekuasaan untuk membuat peraturan-peraturan tertentu yang menguntungkan atau meligitimasi kepentingan kekuasaan.Untuk itu kemudian muncul istilah "sunset clouse", yakni upaya sedikit demi sedikit untuk menghapus TAP MPR sebagai sumber hukum dalam sistem perundangundangan Indonesia. Ini juga yang mendasari proyek evaluasi yang disertai penghapusan secara besar-besaran terhadap TAP MPR(S) ditahun 2003 melalui Sidang Umum (SU) MPR. Mahfud MD menyebut agenda ini sebagai "Sapu Jagat", yakni TAP MPR yang menyapu semua TAP MPR(S) yang pernah ada untuk diberi status baru. ${ }^{6}$

Terhadap berbagai ketetapan MPR/S yang sudah ada dan diwarisi dari masa lalu, telah diadakan peninjauan menyeluruh mengenai materi dan status hukumnya berdasarkan ketetapan MPR No. I/MPR/Tahun 2003 tentang Peninjauan Terhadap Materi dan Status Hukum Ketetapan MPRS dan ketetapan MPR-RI tahun 1960 sampai dengan tahun 2002. Ada ketetapan MPR-S yang dinyatakan sudah dicabut, ada yang dinyatakan masih berlaku sampai terbentuknya Pemerintahan baru hasil Pemilu 2004, ada pula ketetapan yang dinyatakan masih berlaku sampai materinya diatur dengan undang undang.Namun demikian, selain itu semua, sampai sekarang masih terdapat 8 (delapan) Ketetapan MPR/S yang dapat dikatakan masih berlaku sebagai peraturan yang mengikat untuk umum.

Kedelapan Ketetapan Majelis Permusyawaratan Rakyat (MPR) atau Majeis Permusyawaratan RakyatSementara (MPRS) tersebut adalah tentang pembubaran PKI, politik ekonomi dalam rangka demokrasi ekonomi, pengangkatan pahlawan ampere,penyelenggaraan Negara yang bersih dan bebas dari KKN, etika kehidupan berbangsa, Visi Indonesia masa depan, rekomendasi arah kebijakan pemberantasan dan pencegahan KKN, dan terakhir tentang pembaruan agraria dan pengelolaan sumber daya alam, TAP MPR ini berlaku sampai terlaksananya seluruh seluruh ketentuan dalam ketetapan tersebut.

Setelah selesainya perubahan keempat UUD 1945 dan ditetapkannya Ketetapan MPR No. 1/MPR/2003 Tentang Peninjauan Terhadap Status Hukum Ketetapan Majelis Permusyawaratan Rakyat Sementara Dan Ketetapan Majelis Permusyawaratan Rakyat Republic Indonesia Tahun 1960 Samapi Dengan Tahun 2002, maka Dewan Perwakilan Rakyat mengajukan peraturan perundang undangan baru yang disahkan dan diundangkan menjadi UU No.10 tahun 2004 tentang Pembentukan Peraturan Perundang Undangan yang isinya menghapuskan TAP MPR dari hirarki peraturan perundang undangan di Indonesia.

\footnotetext{
${ }^{5}$ Moh Mahfudz MD, Perdebatan Hukum Tata Negara Pasca Amandemen Konstitusi, Jakarta: Rajawai Press, 2010. 32 .

${ }^{6}$ Irwandi, 'Kedudukan TAP MPR Dan Implikasinya Terhadap Hierarki Peraturan Perundang Undangan Di Indonesia', Inovatif, 6.2 (2013), 4.
} 
Ketetapan MPR merupakan aturan dasar atau aturan pokok Negara. Seperti juga dengan batang tubuh UUD 1945 yang berisi garis garis besar atau pokok pokok kebijakan Negara, sifat norma hukumnya masih secara garis besar, dan merupakan norma hukum tunggal dan tidak dilekati oleh norma sanksi. Dengan demikian TAP MPR tidak masuk dalam peraturan perundang undangan tetapi masuk dalam aturan dasar Negara/aturan pokok Negara. TAP MPR juga tidak dapat ditempatkan dalam peraturan perundang undangan karena mengandung jenis norma yang lebih tinggi dan berbeda daripada norma yang terdapat dalam undang undang. ${ }^{7}$

Pada tanggal 12 Agustus 2011, pemerintah mengundangkan UU yang sebelumnya telah dibahas dan disetujui bersama dengan DPR yakni Undang Undang No 12 Tahun 2011 tentang pembentukan peraturan perundang undangan menggantikan UU No 10 tahun 2004. Menelisik subtansi UU No 12 tahun 2011 maka ketetapan MPR dimunculkan kembali dan berada dibawah UUD seperti yang pernah diatur dalam TAP MPR No III/MPR/2000. ${ }^{8}$ Seperti yang dijelaskan diatas, bahwasannya kewenangan MPR sudah tidak lagi seperti sebelum amandemen ketiga, saat ini kewenangan MPR sudah dibatasi, seperti produk hukum yang dihasilkan oleh MPR tidak boleh yang bersifat mengatur (regiling) tetapi produk hukum yang dikeluarkan hanya bersifat penetapan (beschikking).

Oleh Bagir Manan Peraturan Perundang Undangan didefinisikan sebagai "setiap keputusan tertulis yang dikeluarkan oleh pejabat atau lingkungan jabatan yang berwenang yang berisi aturan tingkah laku yang bersifat atau mengikat secara umum". sementara keputusan/penetapan/ketetapan adalah suatu penetapan tertulis yang dikeluarkan oleh badan atau pejabat tata usaha Negara yang berisi tindakan hukum tata usaha Negara berdasarkan peraturan perundang undangan yang berlaku yang bersifat konkret, individual, dan final yang menimbulkan akibat hukum bagi orang atau badan hukum perdata. ${ }^{9}$ Untuk lebih jelasnya dapat dilihat pada table berikut:

\begin{tabular}{|c|l|}
\hline \multicolumn{1}{|c|}{ PERATURAN (REGILING) } & $\begin{array}{c}\text { KEPUTUSAN/PENETAPAN/KETETAP } \\
\text { AN (BESCHIKKING) }\end{array}$ \\
\hline $\begin{array}{l}\text { Umum (ditujukan untuk orang banyak dan } \\
\text { tidak tertentu) } \\
>\text { Barang siapa.... }\end{array}$ & $\begin{array}{l}\text { Individual (ditujukan untuk seseorang atau } \\
\text { beberapa orang, atau banyak orang yang } \\
\text { telah tertentu) } \\
>\text { Dosen A.... } \\
>\text { Setiap warga Negara.... } \\
>\text { Setiap mahasiswa }\end{array}$ \\
$\begin{array}{l}\text { Abstrak: perbuatan tersebut tidak ada } \\
\text { batasnya dan belum tertentu } \\
>\text { Mencuri }\end{array}$ & $\begin{array}{l}\text { Konkrit: perbuatan tersebut lebih nyata } \\
\text { (konkret) dan tertentu } \\
>\text { Mencuri computer }\end{array}$ \\
\hline $\begin{array}{l}\text { Berlaku terus menerus (dauehaftig) } \\
>\text { Berlakunya tidak dibatasi oleh waktu } \\
\text { atau berlaku kapan saja sampai norma } \\
\text { hukum itu dicabut }\end{array}$ & $\begin{array}{l}\text { Berlaku sekali selesai (einmalig) } \\
\text { Berlaku sekali saja setelah ditetapkan } \\
\text { selesai }\end{array}$ \\
\hline
\end{tabular}

Berdasaran hirarki peraturan perundang undangan, TAP MPR berada pada posisi kedua dibawah UUD 1945, ini bermakna bahwasannya peraturan perundangan undangan yang berada dibawah TAP MPR yaitu Undang Undang/Perpu, peraturan pemerintah, perpres, dan perda muatannya tidak boleh bertentangan dengan TAP MPR. Begitu juga dengan TAP MPR, materi dan muatannya tidak boleh bertentangan dengan UUD 1945. Karena peraturan perundang undangan tidak boleh bertentangan dengan peraturan perundang undangan yang lebih tinggi tingkatannya, atau dalam UUD ada ungkapan "the supreme law of the land", dan setiap peraturan perundang undangan harus memiliki dasar hukum pada peraturan yang lebih tinggi tingkatannya.

7 Maria farida Indrati, Ilmu Perundang Undangan (Jenis, Fungsi, Dan Materi Muatannya), Yogyakarta: Kanisius, 1998, 100.

${ }^{8}$ Sirajudin, legislative drafting...49.

${ }^{9}$ Ibid., 40 
Jika ada peraturan perundang undangan dibawah undang undang (PP, Perpres, Perda) yang isi dan materinya bertentangan dengan undang undang tersebut, maka upaya hukum yang dilakukan adalah dengan mengajukan yudisial review kepada Mahkamah Agung yang diatur dalam UU 4 TAHUN 2014 Pasal 11 ayat (92) hurub b dan ayat (3) yang menegaskan, "Mahkamah Agung mempunyai kewenangan menguji peraturan perundang undangan dibawah undang undang terhadap undang undang”. Kemudian kewenangan Mahkamah Agung tersebut juga diatur dalam pasal 31 UU 4 Tahun 1985 yang diubah denagn UU 5 Tahun 2004, menyatakan sebagai berikut:

1. Mahkamah Agung mempunyai wewenang menguji secara materiil hanya terhadap peraturan perundang undangan dibawah undang undang.

2. Mahkamah Agung berwenang menyatakan tidak sah semua peraturan perundang undangan dari tingkat yang lebih rendah daripada undang undang atas alasan bertentangan dengan peraturan perundang undangan yang lebih tinggi.

3. Putusan tentang pernyataan tidak sahnya peraturan perundang undangan tersebut diambil berhubungan dengan pemeriksaan tingkat kasasi.

4. Pencabutan peraturan perundang undangan yang dinyatakan tidak sah tersebut, dilakukan segera oleh instansi yang bersangkutan.

Namun jika ada undang undang yang isi dan materinya bertentangan dengan UUD 1945, maka upaya hukum yang dilakukan adalah mengajukan pengujian materi Undang Undang terhadapa UUD 1945 kepada Mahkamah Konstitusi. Namun hal ini tidak berlaku untuk TAP MPR karena TAP MPR pada hakikatnya tidak dapat digolongkan kedalam peraturan perundang undangan karena mengandung jenis norma yang lebih tinggi dan berbeda daripada norma yang terdapat dalam undang undang. Sifat norma hukum yang terdapat dalam TAP MPR adalah setingkat lebih rendah daripada norma norma dalam batang tubuh UUD $1945 .{ }^{10}$ Adapun upaya hukum yang bisa dilakukan adalah melalui pencabutan atau pembatalan peraturan perundang undangan yang dilakukan segera oleh instansi itu sendiri yaitu Majelis Permusyawaratan Rakyat.

Adanya hirarki peraturan perundang undangan menyebabkan pada adanya konsekuensi hukum, yaitu apabila ternyata peraturan perundang undangan yang lebih rendah tingkatannya materi dan muatannya bertentangan dengan peraturan perundang undangan diatasnya maka yang lebih rendah dapat dituntut untuk dibatalkan, bahkan batal demi hukum. Konsekuensi ini telah dianggap ada walaupun tidak diatur, kecuali ada ketentuan sebaliknya misalnya dalam UUD (UUDS 1950 dan KRIS) disebutkan "undang undang tidak dapat diganggu gugat" bertalian dengan ajaran "supremasi parlemen". Disini UUD lebih dipandang sebagai "asas asas umum" daripada sebagai kaidah umum.

\section{Penutup}

Setelah amandemen ketiga, MPR tidak lagi menjadi lembaga tertinggi negara, melainkan sejajar dengan lembaga tinggi lainnya. Dampaknya, produk hukum yang dihasilkan oleh MPR tidak masuk dalam hirarki peraturan perundang undangan seperti yang terdapat dalam UU No 10 tahun 2004. Namun setelah lahir Undang Undang No 12 Tahun 2011 tentang Pembentukan Peraturan Perundang Undangan, TAP MPR kembali dimasukkan dalam hirarki peraturan perundang undangan yang tata urutannya berada setelah UUD 1945 dan hanya bersifat penetapan (beschikking) bukan pengatran (regiling). Adapun upaya hukum yang dapat dilakukan jika isi dan muatan TAP MPR bertentangan dengan peraturan perundang undangan diatasnya yaitu UUD adalah pencabutan atau pembatalan peraturan perundang undangan yang dilakukan segera oleh instansi itu sendiri yaitu Majelis Permusyawaratan Rakyat.

\section{DAFTAR PUSTAKA}

${ }^{10}$ Maria Farida, Ilmu perundang Undangan...100. 
Tutik, Triwulan, Titik. Konstruksi Hukum Tata Negara Indonesia Pasca Amandemen UUD 1945. Surabaya: Kencana. 2008.

MD, Mahfudz, Moh. Perdebatan Hukum Tata Negara Pasca Amandemen Konstitusi. Jakarta: Rajawai Press. 2010.

Indrati, farida, Maria. Ilmu Perundang Undangan (Dasar Dasar Dan Pembentukannya). Yogyakarta: Kanisius. 1998.

Ilmu Perundang Undangan (Jenis, Fungsi, Dan Materi Muatan) Yogyakarta: Kanisius. 1998.

Sirajudin. Legislative Drafting. Malang: Setara Press. 2016.

Irwandi, 'Kedudukan TAP MPR Dan Implikasinya Terhadap Hierarki Peraturan Perundang Undangan Di Indonesia', Inovatif, 6.2 (2013). 